\title{
Searching for the plot: narrative self-making and urban agriculture during the economic crisis in Slovenia
}

\author{
Petra Matijevic ${ }^{1}$ (D)
}

Accepted: 9 July 2021 / Published online: 24 July 2021

(c) The Author(s), under exclusive licence to Springer Nature B.V. 2021

\begin{abstract}
Analyses of household urban agriculture have demonstrated a wealth of personal, economic, social, moral or political uses for self-provisioned food, yet have often understood the practice itself as merely a production process. This 'means-to-an-end' perspective is especially pronounced in studies of locations undergoing economic hardship. Urban gardening in postsocialist Central and Eastern Europe and the former Soviet Union has been framed as an element of an informal economy, enabling household savings, access to informal networks and avoidance of industrial goods deemed ethically dubious. In this article, I present evidence from participant observation and interviews with urban gardeners conducted in 2014-2015 in Ljubljana, Slovenia, where urban agriculture proliferated during the European debt crisis that began in 2009. I interpret the material through an ecological perspective that focuses on labour in nature and highlights the interconnected, situated role of the gardener. My analysis of gardening styles, behaviours, attitudes and life-narratives of long-term urban growers challenges the utilitarian interpretation by arguing that urban agriculture in Ljubljana is in fact a means in itself-not an informal economy, but a narrative practice. While undertaken to ameliorate the effects of economic hardship, household urban agriculture first and foremost promotes individual wellbeing and restores a stable sense of self. I outline a series of self-making benefits of working with cultivated, edible nature that helped gardeners reconstruct their biographies after their previously established self-making processes collapsed in the economic downturn.
\end{abstract}

Keywords Slovenia $\cdot$ Central and Eastern Europe $\cdot$ Urban agriculture $\cdot$ Gardening $\cdot$ Narrative $\cdot$ Self-making $\cdot$ European debt crisis

$\begin{array}{ll}\text { Abbreviations } \\ \text { CEE } & \text { Central and Eastern Europe } \\ \text { CSA } & \text { Community-supported agriculture } \\ \text { DGA } & \text { Dobrava Gardening Association } \\ \text { EU } & \text { European Union } \\ \text { FSU } & \text { Former Soviet Union } \\ \text { WWII } & \text { World War II } \\ \text { OECD } & \text { Organisation for Economic Co-operation and } \\ & \text { Development } \\ \text { SURS } & \begin{array}{l}\text { Statistični Urad Republike Slovenije (Statistical } \\ \\ \text { Office of Republic of Slovenia }\end{array}\end{array}$

Petra Matijevic

petra.matijevic@gmail.com

1 Independent scholar, Edinburgh, UK

\section{Introduction}

To approach urban agriculture in the social sciences is often to appraise its potential to remedy economic and social ails. Researchers ask, what can urban agriculture do? The bar is set high — can it ameliorate a broken food system to distribute sufficient and adequate nourishment in a sustainable way (Dwiartama and Piatti 2015)? Build a resilient food supply system able to withstand extreme weather and volatile market movements (Altieri et al. 1999)? Can it revitalise urban communities by greening neighbourhoods; inspire reflections on social justice and political change with participatory democracy (Lyson 2012; Poulsen 2017); improve the situation of people in correctional, educational or health institutions (see Pudup 2008)? The potential benefits of urban agriculture are summoned at times when economies or societies crumble.

In places where vegetable cultivation is already an integral part of the urban backdrop, researchers approach it from the opposite side. They ask, what is urban agriculture 
a symptom of? Which social conditions compel citizens to practise it? Urban and peri-urban agriculture is widespread in Central and Eastern Europe and the former Soviet Union (CEE and FSU) and can have a significant effect on the national economies. For example, 90 percent of the potato crop in Russia is purportedly grown on household plots (Ries 2009). Urban gardens in the former socialist member-states of the European Union (EU) produce up to ten times the amounts produced by their Western EU counterparts (Alber and Kohler 2008). Political leaders in CEE, who attempted to graft capitalist markets onto the state-planned terrain after the collapse of socialism, promised an affluent and lively consumer culture. Despite this, household self-provisioning practices failed to disappear. Observers of the postsocialist economic crises emerging across the region have interpreted this persistence mainly through the frame of the informal economy-seeing it as motivated by a desire to decrease household dependency on the market, either because the market had not been working well (Bridger and Pine 1998) or because it had been working in a way deemed morally unacceptable (Gudeman and Hann 2015).

In both approaches to urban agriculture, the practice is a means to an end-a black box accepting an input of labour and returning a nourishing good that can then serve personal, social, moral or political ends. The process of food cultivation itself is not usually the focus of analysis. The premise that the food product unlocks the benefits of urban agriculture is challenged even less in times of economic disruption, since the experience of economic hardship goes hand in hand with efforts to reduce food expenditure, expand market reach or gain access to mutual aid networks via nonmonetary exchange.

In this article, I will argue that insufficient attention has been given to the practice of food cultivation as a means in itself and to the benefits of urban agriculture that go beyond the utility of the produce. I will propose that an examination of urban agricultural work is key to unlocking the benefits of urban agriculture, especially during economic crises, when coping with the consequences of hardship may be even more important than agriculture's ability to offer sustenance or goods of informal exchange.

The consequences of a grave and long-lasting economic crisis-loss of steady, secure income from full-time employment, for example - go beyond scarcity, lack of economic security or of a social safety net. Under the heading of 'precarity', anthropologists have begun to collect the devastating psychological consequences that may come with the experience of uncertainty about what is to come, with increased dependence on others for survival and with the collapse of daily routines. These experiences can lead to a loss of one's routine temporal structure, and to a sense of purposelessness and ineffectualness. Precarity collapses the self by unmooring one from a shared passing of time, shatters a sense of biographic continuity and takes away personal worth and intelligibility of one's actions and behaviours (Khosravi 2017).

I will argue that interacting with an urban garden offers a unique way of coping with precarity. My argument rests on the experiences of long-term urban gardeners and on how they surmount two entry barriers to the activity of gardening. The first barrier is the high time-investment needed to keep a vegetable garden and implies that time availability, more than one's prior horticultural experience, equipment or income level, determines, in the first instance, whether one will likely adopt the practice long-term. The second barrier is the gardener's lack of complete control over the outcomes of vegetable cultivation. I adopt a perspective that sees the experience of gardening as one of participating in an assemblage. In an assemblage - a 'loosely imagined grouping' (Gan and Tsing 2018) — humans, plants and other organisms cooperate and coordinate the garden matter in ways that are never entirely predictable. This second step helps me answer the question of why those with few external demands on their time should choose to invest it in the horticultural practice. It then allows me to link the gardener's partial control of the garden with the practice of biographical narration.

In the countryside, limited control over the food production process forces farmers to organise their activity around managing the intrinsic uncertainty of agricultureby accepting risks, working with constraints, learning from signs and respecting what lies beyond their control. Being attentive to change, adapting after a bad season and using one's labour strategically are key to survival on the farm (Berger 1979; Gudeman and Rivera 1990). Cultural phenomena at the heart of what makes us human-values, beliefs, gender and kinship roles, calendars, systems of honour and ideas about the body - help us to cope and overcome uncertainty (see Bourdieu 2000; Caldwell 2011; Mroczkowska 2019). In the city, the necessity of developing agricultural skills is less essential for the household's subsistence, but it is as likely a source of meaning. I propose that, in the absence of employment, affluence or a structured everyday schedule, managing the uncertainty of agricultural practice during an economic crisis imbues the grower with the ability to translate their work into an activity with social and moral value and, consequently, to mend their self-narrative.

Previous analyses have tended to overlook these two components of urban vegetable cultivation-high time-investment and the gardener's lack of complete control—but their acknowledgment is crucial to understanding the increased motivations for tending a vegetable plot in times of crisis.

To support my proposed approach, I will present ethnographic evidence collected by working alongside urban agriculturalists in Ljubljana, Slovenia at the tail of the European debt crisis, between 2014 and 2015. While vegetable cultivation on private, dislocated plots has been a characteristic of 
the Slovenian capital city since the post-WWII urbanisation, the popularity of urban gardening sharply increased in the wake of the global recession that started in 2009. This article asks: What were the motivations driving this increase? Taking into account the tenuous relationship between the gardener and the garden ecology, I will first select a subset of gardeners who have overcome the hurdles of time availability and uncertainty. I will show that the urbanites who overcome these hurdles are those whose biographic impasses have prompted them to seek outlets for spending their time meaningfully; they tend, too, to be unemployed or retired. I argue that the more likely collapse of life-narratives in times of social disruption accounts for the increases in the urban gardening practice. In the second part, I will outline five benefits of urban gardening connected to its ability to re-structure self-narratives in a time of precarity, on the basis of observing and working with long-term gardeners.

The article contributes to the emerging body of knowledge exploring care and companionship in human-plant relationships (see Degnen 2009; Archambault 2016; Gan and Tsing 2018), by illustrating how cultivating vegetables can reconstruct the self when previously established ways of selfhood construction collapse in economic and political downturns. The article contributes to the discussions about the health and wellbeing of gardening, by proposing that the benefits for health lie with the work of gardening and its symbolic social meaning, rather than with an external factor such as produce, socialising or exercise.

The article is structured in the following way. The next section reviews the approaches to urban agriculture that investigate the motivation behind the activity, and proposes an alternative, rooted in the evidence I collected for this study. The Background and methods section sketches out the geographical and political landscape of this study and outlines the methods used in my research. The results and discussion span two sections. Why some gardening projects fail and others flourish uses data from semi-structured interviews and desk-research methods to explore biographic patterns of long-term urban gardeners. Self-making on the plot examines the gardening style and behaviour of long-term plot-holders and uses material collected from participant observation, semi- and unstructured interviews and autoethnography to describe five proposed benefits of urban gardening. The conclusion addresses the implications of the argument for research and policy.

\section{A narrative approach to motives for urban agriculture}

The studies of urban agriculture in postsocialist CEE and FSU tend to explain its dynamic through participants' economic motivation. This seems partly a consequence of what the studies are arguing against. International policy has often framed postsocialist urban agriculture as a symptom of underdevelopment and of a "strong preference for owning the land" (OECD 2001, p. 24). To counter this perspective, research on self-provisioning in CEE and FSU has taken one of two directions. Some saw it as a response to a demand-side problem-a moral refusal of what capitalism had to offer (Pine 2002; Dunn 2008; Jung 2014). Others described it as a reaction to disruptions of supply-as an informal economy erected on the foundations of the disastrous economic effects of socialist dismantling (Bridger and Pine 1998). Researchers challenged claims that urban agriculture offered survival to those too poor to participate in postsocialist economies. They showed that those who grew food continued to rely on market produce, while those at the very bottom of the economic scale possessed neither skills, tools, nor time to produce sustenance themselves (Clarke et al. 2000). Instead, vegetables from urban plots were understood as pathways to boosting meagre incomes (Round et al. 2010); accessing community mutual aid (Czegledy 2002); or restoring one's sense of dignity and preparedness (Hervouet 2003; Zavisca 2003; Ries 2009).

With its insistence on the social circumstances that inspired people to seek the garden plot, the informal-economy approach emphasised the social inequalities propelling postsocialist households to produce food within the household. Their argument that the strong presence of urban agriculture in CEE and FSU was caused by the socioeconomic circumstance of postsocialism was reinforced by the evidence of a far smaller extent of the practice in more affluent Western Europe. Yet, as other research has shown, the informal-economy approach failed to consider alternative factors for increased horticultural productivity in the CEE and FSU region. Slower urbanisation and historic land tenure regimes in postsocialist countries may have retarded the growth of urban density and left a larger store of arable urban and suburban land (Stenning et al. 2011). In showing how larger yields and higher national economic impact of urban agriculture may be nurtured simply by there being more space available for urban cultivation, research by Stenning et al. highlights the fact that urban agriculture is always and everywhere a historical phenomenon, evolving through interaction with the local environment and thriving when supported by its environmental, administrative, demographic and other relevant conditions.

Approaches that focused on the activity of gardening have been sparse and have ordinarily relinquished the insistence that social inequality played a decisive role in driving urban agriculture. Critics of the postsocialist utilitarian perspective demonstrated how local ideas about the self, body and wellbeing, unrelated to the economy, underpin city cultivation (see Caldwell 2011; Jehlička and Smith 2011). Their work built upon the studies of allotments in the UK, which 
understood urban agriculture as a form of leisure, a goal in itself (see Thorpe 1975; Bhatti and Church 2001; Tilley 2008). However, here the urban agricultural practice served only as a methodological window-onto constructions of national and individual identity and relationships with nature-making this strategy ineffectual for studying its social motivations.

A number of studies of the benefits of working in the garden have focused on the correlation between interaction with the natural environment and improved physical and mental health. These studies have proposed that the positive effects of immersion originate in our physiological or psychological predispositions (see Berman et al. 2008; Sacks 2019). A range of other disciplines, from biology to geography, has investigated the benefits of urban agriculture for the environment and society and its political motivations (see Ferreira et al. 2018; McClintock et al. 2018; Nogeire-McRae et al. 2018; Wachsmuth and Angelo 2018). ${ }^{1}$ These works are reflected in the popular discourses that attribute the positive effects of gardening work to factors entirely external to the practice, such as fresh air or the opportunity to socialise on the plot.

To account for the unequal social circumstances that may prompt some to seek the embrace of urban gardening, while also stressing the practice itself as important, an alternative approach is needed. My proposed approach has two steps. The first requires a shift from treating an urban garden as an economy producing goods and benefits for social reproduction towards appreciating it as a 'multi-species assemblage' (Haraway 2008). An urban garden is an ecology, a swarm of life. As any farmland, it is an agglomeration of humans, non-human organisms, of matter and ideas. Unlike systems organised around a central idea that determines the relationships between its elements, assemblages are 'unruly'; things in an assemblage "hold' "without a unified purpose or design" (Gan and Tsing 2018, p. 102). Assemblage is a "mode of ordering heterogeneous entities so that they work together for a certain time" (Müller 2015, p. 28); a multiplicity of temporary productive relations rather than durable hierarchies. In assemblages, humans and non-humans may have different goals but align with each other through temporal coordination (seasonality and daily rhythms); attentiveness to one another; openness to chance encounters and events; and taking opportunities (Gan and Tsing 2018). Although the multispecies ethnography scholarship often uses the garden as an example of the assemblage's antithesis, as the product of human desire to master nature and impose order (see Gan and Tsing 2018, p. 131), I maintain that such control is an illusion. Garden plants may be

\footnotetext{
${ }^{1}$ I would like to thank one of my reviewers for making me aware of these works.
}

enlisted for specific goals set up by human growers, but gardening, like farming, is a relationship of cooperation, not complete authority.

The second step of my proposed approach is to recognise this participatory indeterminacy as the meaning-making element of the practice and, thus, the basis for its value.

The world is an overwhelming stream of disjointed events unless adaptable 'versions of reality' order them into a coherent whole (Ochs and Capps 1996). The self is one such theory of reality; it is a best-fit model for subjective experience, giving meaning to life lived and guiding interpretations of future experience (Ochs and Capps 1996; Bruner 2003). The self is actualised "through the activity of narrating" (Ochs and Capps 1996, p. 29); the narrative self is "teleological, replete with desires, intentions, aspirations, endlessly in pursuit of goals" (Bruner 2003, p. 213)-like the plot of a novel. But the narratives require both a social foundation for their plot and a constructed past for continuity with events in the future. They thus acquire a 'genre' of life (Berlant 2011), i.e., a patterned way in which life unfolds in accord with the socially prevalent 'structures of feeling' (Williams 1977). The individual's agentive power manifests itself in balancing these two sides. On the one hand, a selfnarrative must "create a conviction [...] that one has a will of one's own, a certain freedom of choice, a degree of possibility. However, it must also relate one to a world of others- to friends and family, to institutions, to the past, to reference groups" (Bruner 2003, p. 218).

Plot twists, or self-narrative 'turning points', that give character to the subject of a life story, are "efforts to individualise a life" (Ochs and Capps 2001, p. 73). But certain life events can shatter our ability to sustain our theory of reality. Post-traumatic stress disorder follows an experience "too devastating to incorporate into one's life story"; depression and anxiety may arise from 'silencing' embryonic variants of autobiography that stray from the dominant personal blueprint for life (Ochs and Capps 1996, p. 30). On the other hand, narratives cannot be constructed in the absence of social scaffolding. Without a space of safety and reflection from which to transform events into lessons learned or memories to cherish, the predominant feeling sensed by homeless urban residents is boredom-the absence of a meaningful narrative (Desjarlais 1997; O’Neill 2014).

The sense that our lives lead somewhere depends, therefore, on other people and on things beyond our control (Butler 2004; Hage 2009; Berlant 2011). Stable social templates help individuals to translate events into shared, meaningful experience. Severe economic downturns, such as the 2008 global recession, shatter the established templates for life-for example the personhood of a worker, structured by capital, state welfare, aspirations, ideas about gender and solidarity (see Muehlebach 2012) — and peel back the layers of security and predictability. Over the past decade, precarity 
has served scholars in the humanities as the main heading under which to collect evidence of human suffering caused by such uncertainty, from the immobility of being unable to predict what is to come (De Boeck 2015; Jansen 2015; Bryant 2016), to the consequences of needing to depend on unpredictable others in the wake of crumbled social security (Muehlebach 2012; Millar 2014; Narotzky and Besnier 2014).

Faced with social uncertainty, we may persist in our attempts to make lives meaningful, because an absence of meaning is difficult to bear. We may attempt to manufacture meaning in four main ways. One, while we may no longer reasonably expect that we will find a job, a partner, make a family or retire in good health, we may insist in our attachment to them-sustain a 'cruel optimism' (Berlant 2011). Two, we may attempt to better control future events by controlling our bodies and possessions, however psychologically and physiologically unsustainable. Eating disorders and compulsive hoarding are narrative activities-ways of overcoming powerlessness (Berlant 2011). Three, we may choose an alternative narrative structure in which to interpret life events. The rise of interest in astrology, spiritual practices or alternative healing, for example, has been long tied to a quest for certainty that could frame everyday experience (Adorno 2001). Four, we may create meaning extemporaneously. We may choose to spend time or exert energy in exchange for a meaningful outcome.

In situations where the outcome is beyond our control, we may attempt to cope with the uncertainty by opting for 'practical intelligibility' (Schatzki 2010; also see Bryant and Knight 2019). We may avoid certain choices because they threaten to render our past actions an unusable building block in our life-narrative and choose to do whatever promises us a more meaningful outcome, for the sake of minimising loss. Waiting in a slow queue at the supermarket because moving to another would mean that the time we already spent waiting would have been in vain; staying in an unfulfilling career because changing it would devalue our time heretofore invested. This sunk-costs form of reasoning engineers a meaning of our actions by using the investment of time and energy to acquire a vested interest that the outcome, whatever it may be, will be favourable for us in some way. Our actions must have served an end, we will tell ourselves.

I propose that long-term urban gardening is a practice of manufacturing meaning in the face of unmanageable social uncertainty, by combining several meaning-making techniques to alleviate it. The relatively structured nature of gardening, yet one never entirely under the gardener's control, leaves space for chance occurrences and surprises yet allows the gardener to assert their agency by controlling what they can and allowing the rest to render the background of their biographic narrative.
This two-step approach allows me to answer an old question of the motives for urban gardening in a new way. I will show how the practice appeals because it offers a structured template for work, sparks off collaboration, transforms the invested time and energy into a stake in the future and imbues the grower's work with social and moral meaning. Together, these benefits help an individual to revise their autobiographical plot and to reposition its main character as an agent of their own fate.

\section{Background and methods}

A flourishing urban vegetable garden in Ljubljana (called vrtiček in Slovene, a diminutive for garden) will be between the size of a studio flat and a basketball court. It will often house a tool shed, shade for rest or a small plastic greenhouse. It will be cultivated by a single household and, if dislocated from the household residence, it will lie within a short bicycle ride from it. It will grow lettuce (several kinds), chicory, potatoes, tomatoes, onions, beans, peas, radish, cucumber, courgette, strawberries, some flowers, perhaps a fruit tree or a bush. It will need a number of things to produce food in abundance. Inputs such as land, soil, seeds and seedlings; sun and temperate climate; and water will need to be accessible. Land on the outskirts of Ljubljana is abundant due to a combination of factors. Geographical givens, historical land-tenure regimes, municipal policy and environmental conservation laws limit intensive farming and urban development. More than 200 plot garden sites (Jamnik et al. 2009, p. 65) are sprinkled around Ljubljana's edges. Some of them occupy land with the explicit consent of the owner, others do not; some have running water and fertile soil; some thrive more than others. ${ }^{2}$ The gardens tended by the members of the Dobrava Gardening Association (DGA, a pseudonym), the oldest such organisation in Ljubljana, are particularly beautiful and bountiful. The organisation rents good-quality farmland on oddly shaped patches on the outskirts of the city and has its own water supply network that the members have installed in the past.

On a late autumn evening in 2014, I visited the DGA office to speak to its president and put my name on the waiting list for a vegetable plot. I wished to understand the nature of the sudden increase in practices of self-provisioning in the fallout of the European debt crisis and hoped to get in touch

\footnotetext{
${ }^{2}$ The vrtički urban gardens, akin to the British allotments, are not the only type of vegetable gardens in Ljubljana. There are two inner-city, semi-professional vegetable farms with a long history (Jamnik et al. 2009). Several communal garden initiatives have also been established since 2010. These forms, however, represent a fraction of the urban gardening activity in Ljubljana and ordinarily do not host amateur gardeners who tend the land for prolonged periods.
} 
with seasoned plot-holders who could share their experience with the popular and most visually exposed form of self-provisioning in Ljubljana. In cities with a population above ten thousand, 15 percent of households residing on housing estates reported growing some of their food themselves, according to a household survey conducted in 2012 (SURS 2012). Since housing estates ordinarily do not have a space dedicated to vegetable gardening, this proportion stands for the share of households that cultivated a dislocated vegetable plot. Media perspectives on the practice had been rapidly shifting. Gardening plot sites, a traditional backdrop to the city of Ljubljana, were often sneered at by local newspapers and national dailies in the 1990s and 2000s for their shabby appearance and informal use of urban space. Since the recession, urban plots began to be depicted as a clever source of food provisioning, both supplemental to the market - thrifty—and superior to it—providing healthy, wholesome, local food that money could not buy. The City of Ljubljana local authority started taking a more hands-on approach with plot garden sites occupying municipal land. ${ }^{3}$

According to the association's application records from late 2015, which I reviewed with permission from the president, the organisation corralled around 350 households from nearby housing estates in 2015 , to cultivate plots on a handful of sites, with an average size of $110 \mathrm{~m}^{2}$. He has led the organisation since its formal establishment in 1985 but plot garden cultivation on the DGA territory began much earlier, with the post-WWII reconstruction efforts in the Socialist Federal Republic of Yugoslavia. After a heavy-industry processing plant was erected on pristine farmland outside the city, the vegetable patches began to line the surrounding area to provide temporary housing in the garden sheds for builders and factory workers and to supply the factory kitchen with vegetable produce. With the growth of the city over the next decades, plot gardening got a leisurely feel and was sustained by the free time available to households during the socialist period. Factory shifts that started and finished early (from 6-7 a.m. to 2-3 p.m.) freed up the afternoons. The shift to a market economy following the collapse of socialism in 1991 has altered patterns of employment and leisure. Work shifts have moved to midmorning starts and became longer and less predictable. From its status as a worker's leisure activity, plot gardening became the domain of those with more time on their hands.

New membership requests had usually come in a steady, gender-balanced trickle, according to the president, but, since 2010, the DGA had been noticing a surge in demand.

\footnotetext{
3 The Ljubljanian municipal governance of the urban gardening practice is a fascinating and highly contested subject, deserving of publication in its own right. It falls outside the scope of this paper, which approaches gardening as a form of personal coping with precarity during economic and social crises.
}

The association's application records showed that more than 40 percent of their members had been given a plot after 2010. Students and young families wanting to enjoy affordable organic produce represented a sizeable share of the office hours walk-ins but they tended to give it up as soon as peak season overwhelmed them with work. However, another group of people who joined the DGA in greater numbers ended tending their plots for longer periods: these were Ljubljanians who had lost their jobs or exited full-time employment. In the president's view, the period of austerity measures during kriza ('crisis', referring to the fallout of either the European debt crisis or the global recession that caused it) had motivated households experiencing economic hardship to begin cultivating vegetables in the city.

Slovenia was badly hit by the 2009 European debt crisis. Its small and import-dependent domestic market, its overblown banking sector and its quick adoption of the euro currency in 2007, three years after joining the EU, contributed to a steep economic downturn: a decline of the economy by $8 \%$, one of the largest drops in the EU. Slovenia narrowly avoided a bailout by the infamous 'European troika' with cuts to public spending, including welfare provisions, and privatisation (Guardiancich 2013). Elevated levels of unand underemployment (from 7\% in 2008 to $13 \%$ in 2013), especially in low-skilled work; increased proportions of precarious and temporary employment; rise of poverty; increased out-migration; protests and political instability followed (Zorc 2013; SURS 2014; Intihar 2017). Ljubljanians were forced to spend their leisure time making ends meet (Filipovič Hrast and Rakar 2015; Dragoš 2016).

I conducted ethnographic research of urban gardening in Ljubljana during the 14 months between summer 2014 and autumn 2015. Along with the employment of a wide range of qualitative, quantitative and desk-research methods (Marcus 1995), an important characteristic of ethnography is that its research data are rarely detachable from its interpretation. The recording of data through observation and conversation is inevitably coloured by the researcher's subject position (Gupta and Ferguson 1997). To get a sense of my surroundings, I first surveyed Ljubljanian urban agriculture. I visited 13 sites where I conversed informally with 57 urban growers or urban growing households, noting down their experiences, obstacles and challenges, documenting their stated reasons for having started the activity, length of tenancy, socio-economic position, occupation, age and household size. I clustered the visited gardening projects according to the duration of their tenancy. I then narrowed the scope and set out to determine which factors made a gardening endeavour more likely to succeed. I investigated a subset of gardeners whose gardens had been maintained for longer than three seasons and which gave a good return. I conducted 25 semi-structured interviews that asked my collocutors to narrate their life history (see Mintz 1979), 
reflecting on their upbringing, careers, families, economic position and household dynamic. I recorded and transcribed the interviews. I have analysed the transcripts for patterns, specifically mentions of 'turning points' - the events leading to their decision to tend a garden plot - and to the style of describing their biographies since they started gardening. I also noted down any garden-site gossip about my collocutors to get an indication of how their circumstances were perceived by their neighbour gardeners. I have compared the biographic patterns that emerged with examples from literature (e.g. Gudeman and Rivera 1990; DeLind 1999). My findings that refer to an alternative reading of the urban gardening practice are summarised in the following section.

To better understand the benefits of gardening practice, I rented a plot on one of the garden sites. I visited regularly and cultivated vegetable crops for the length of a gardening season. Learning from ten of my closest neighbours and putting their lessons into practice allowed me to observe details of the gardening style of long-term gardeners that might otherwise have gone unnoticed (the method of apprenticeship, see Wacquant 1998). I also acquired a sensory experience of gardening labour (the method of autoethnography, see Anderson 2006). I analysed my field notes describing my experiences, the accounts of my neighbours' experiences and the noted observations about their gardening by looking at the material through the lens of motivation. This interpretation contrasted with the gardening techniques that would prove sensible had their vegetable cultivation been an act of an informal economic production (e.g. improving yield). I grouped the themes that emerged into five clusters. The proposed five benefits of plot gardening are described in the Self-making on the plot section.

\section{Why some gardening projects fail and others flourish}

While surveying urban agriculture in Ljubljana, I asked the vegetable growers what their intended aims for gardening were. The most frequent response I recorded among those who had kept a garden five or more years was: "You save a bit of money, you grow some fresh vegetables, you get some fresh air and a bit of exercise... And you make some good company." This recorded statement matched the ones captured by empirical surveys in Slovenia and elsewhere (Jamnik et al. 2009; Smith and Jehlička 2013). Yet when novice, aspirational vegetable growers took up urban agriculture to pursue these very goals - to lower household expenses, to produce good and healthy food, to spend time outdoorstheir projects frequently stumbled. Brigita, a mother of two teenage daughters, whom I helped in the garden and with whom I often chatted over coffee in her kitchen, began cultivating a large vegetable plot after she became unemployed. Her aim was to save money and to grow fresh produce. She gave up the garden after a year, feeling unable to ignore the fleeting opportunities to make some cash with odd jobs, and thus finding herself short on time for gardening. Similarly, young parents who eagerly dug their hoes into the early spring soil to grow organic vegetables for their children forfeited their plots to weeds in high summer when the needs of the garden became too much to handle. The fate of a student-led community garden on the halls of residence campus was similarly precarious. The project was set up with the intention of cajoling students out of their isolated rooms and into meeting one another outdoors. Its instigators, with whom I worked, soon ended up burdened with the glut in need of distribution or processing and struggled to overcome petty resentments over the imbalance of invested gardening labour.

I found an analogous ethnographic example in a rare, candid rendition of a failure steering a community-supported agriculture (CSA) scheme from an academic researcher in Michigan, USA (DeLind 1999). For the founding members-the author among them- the CSA was to be an act of social resistance: the farm was to be a commons, grounded in an appreciation of ecosystems, local community and sharing of responsibilities along the food supply chain. Yet once farming was underway, the researcher wrote, the CSA members began congregating into two camps. The CSA shareholders began behaving as consumers; they were reluctant to work on the farm and turned up only to pick up the boxes of 'chemical-free, fresh vegetables'. The founding members adopted the role of food producers; they worked strenuously, absorbed the risks personally and ended feeling overworked and no longer connected to the earth and community as they had planned. Tensions, resentments and self-exploitation eventually led to the closure of the CSA. DeLind stressed that a lack of horticultural knowledge did not contribute to the project's demise and concluded that, ultimately, their CSA closed down because its members were unable to avoid the "pervasive market mind set" since their diets did not depend on the produce they grew themselves (DeLind 1999, p. 5).

While the lack of technical knowledge or access to equipment was also not the issue in the failed projects I encountered, not caring enough about the goals of their urban agricultural initiative was not a reason for their lack of success. Rather, their failure was more likely related to the novice's receptiveness to policy and media ideas about the practice. Approaches to urban agriculture advocating its concrete, material benefits tend to regard the observable effects of urban horticulture-harvest amounts, economic indices, interviewees' statements - as identical to the growers' initial reasons for taking up the practice. In assuming a frictionless transition from the spark of motivation to the harvest finish line, such approaches presuppose that an urban garden is a pure expression of the intent of the grower, and therefore 
that urban agriculture is an effective means to an end, that it is fully under the grower's control, and that it is merely in selecting the appropriate goal, be it organic food, household savings or community building - and then sticking with itthat success lies. In times of acute economic crises, surges in urban agriculture have been associated with benefits for increasing household self-sufficiency. The media and policy discourse accompanying the European debt crisis in Slovenia insisted on the sensibleness of producing cheap and healthy food yourself when procurement from the market became more difficult (Vrtičkarstvo v Ljubljani 2016). The discourse echoed the portrayals of the practice in the newspapers during the 'stabilisation' period of austerity in Yugoslavia during the 1980s (Burnik et al. 1984) and the more famous 'Dig for Victory' campaign during the WWII in the UK (Ginn 2012). However, the accounts of failing gardening projects that I collected both in the field and in the literature suggest that, the more strictly one defines one's goal, the less likely one is to reach it. In the garden, plans are slippery. Robust expectations and grit are not enough to sustain the projects, which are never the result of growers' intentions alone. In surveying gardening projects across Ljubljana and analysing my own struggles to keep a vegetable patch, two main reasons for failing to keep an urban plot emerged: first, a lack of time allotted to working and, second, a failure to tackle the uncertainty inherent to the gardening practice.

The ingredient, most crucial for sustaining a flourishing garden, is a sufficient input of human labour. Without human work, the garden assemblage will still 'hold', but it will be taken over by weeds. A flourishing horticultural garden in Ljubljana's continental clime is labour-intensive and demands dedicated work. Only those able to endure the summer heat, carry infinite watering cans, not cave under the unremitting need for weeding, and stay vigilant in pest inspections will see a successful end of the gardening season. Only those able to keep up with the obligations and putting the needs of the garden first will reap the rewards. Keeping a vegetable patch also demands an adjustment to its rhythms. On the plot, work is governed almost entirely by the requirements of the garden. Once your chosen crops begin to flourish, once the ecology gets going, very little is left up to you. The garden cannot wait. Pick a courgette half a day too late and it will turn into an insipid marrow. A few days of neglect, and weeds will spread out, the seedlings will shrivel. The daily watering and weeding and the seasonal sowing and harvesting must be done at the right time, not when there is time to spare. Gardening projects that do not invest sufficient time, at the right time, will likely fail.

Furthermore, as subsistence farmers know well, growing food is governed by chance; abundance cannot be taken for granted. "Because the land has powers that lie outside human control, agriculturalists can never count upon getting a return," observed Gudeman and Rivera (1990, p. 26).
Crops might fail for numerous reasons. The Colombian farmers who worked with Gudeman and Rivera described land cultivation as a 'gamble', a 'lottery' and a 'venture', to express the risk involved. This matched my own observations. Urban agriculture is similarly unpredictable and shaped by additional, city-specific factors, from urban planning programmes to night-time produce-theft. Projects that make no room for indeterminacy, for open-ended collaboration of garden participants, will likely fail.

Who can overcome the initial difficulties? Who does not give up? My research found that long-tenured gardeners, in general, will be those with not only sufficient free time to tend the plot but a need to spend it. During my gardening tenure, I became privy to the garden site gossip. The whisperers were quick to point out a grower who seemed too affluent to have a real need for gardening. "Why on earth does he need a plot?' my neighbours would say, under their breath, about a plot-holder who drove to the site in a BMW car. Yet material wealth and income were not the key criteria of entitlement that arose in these chitchats. Many other factors were collated by the garden busybodies into a fuller profile of a gardener: someone's marital status, how well they got on with family and friends, did they have medical issues or problems with alcohol. These exchanges suggested that being compelled to seek the haven of the plot was closely related to a particular life situation.

When I talked to long-term Ljubljanian plot-holders about how they came to keep a plot, their narratives revealed a pattern. The life-stories of gardeners who tended gardens year after year were more likely to include a biographical impasse. Đurđa, ${ }^{4}$ my east neighbour on the gardening site, began gardening when she lost her job as a manual factoryworker at the beginning of the European debt crisis, at the age of fifty-five. Being close to retirement age, she lost hope of finding another employment. She was diagnosed with depression. After acquiring a plot, she told me, she felt "born again". Her days were full and orderly, spent in purposeful activity that supplied her household and her children's families with the vegetables they enjoyed. Time was propelled forward by suspense over what the gardening season would bring. My collocutors reported other life-shattering events that led them to acquire a garden: the death of a young adult son, the loss of a life-partner in old age, the isolation of retired life. Cultivating vegetables can lend a turning point to a life story. Personal tragedy, misfortune or feelings of being stuck suggest that those who most successfully tend their plots are those brought to the site by a need for autobiographical repair. On the garden plot, Ljubljanians search for the plot of their life-story.

\footnotetext{
$\overline{4}$ All forenames in this article are pseudonyms.
} 
In times of economic disruption and hardship, the previously stable social structures of secure employment, homeownership and retirement can no longer be relied upon and a sense of purposefulness can therefore no longer be gained from investment into them. Biographic impasses become more likely. For the majority, the daily experiences of hardship necessitate a scramble to make ends meet, taking an extra toll on their time. But a group of people will be rendered unemployable by the crisis and will be pushed out of their role as productive members in society. Their freed-up time will come with a need to spend it engaged in a socially sanctioned, productive, collaborative and immersive practice. These will be the ones whose gardens will thrive. The next section will now drill down into the elements of gardening that help alleviate precarity and piece together one's life-narrative.

\section{Self-making on the plot}

In the windless afternoon heat in July 2015, I was digging out my very first potato crop on a narrow vegetable garden managed by the DGA. Narrow paths divided our site-a patch of farmland near a traffic artery-into dozens of plots. I was cultivating an area half the size of my neighbours' but I found it difficult to keep up with them. To my delight, I kept unearthing giant spuds. "Oh, how good you are (kako si pridna, hard-working)," said a passer-by. Zorka, my northfacing neighbour, was a defiant octogenarian Serb with forty years of vegetable cultivation under her belt. She seemed impressed by my harvest and wished to learn the variety of potato I had planted. To a novice relying on neighbours' advice, her curiosity was flattering. My pride soured when later that day Đurđa stopped by to see the miraculous crop for herself. She had run into Zorka and the two had been chatting about me. Zorka had bemoaned the injustice that a beginner like me should be graced with such a good crop. Bemused, Đurđa told me not to worry about a little gardener's envy. The following day, Zorka decided to dig out her own vast potato patch with the help of her husband and son. Her head suddenly appeared through the curtain of climbing beans dividing our plots; her eyes were shining. "Hey, come over here, come see!" At her feet lay a small mountain of papery-skinned, sooty tubers even bigger than mine. In all her time on this plot, she said, she had never witnessed such a generous potato season. The family filled the boot of their car with six twenty-kilogram crates, feeling that they too, like me, had got lucky this year.

For Zorka, austerity had been particularly hard. The set of policy measures introduced in 2012 put a cap on her small pension. Her only child, a son in mid-forties, had had trouble finding a job since the crisis. Her husband had been suffering from reduced mobility from Parkinson's disease. Yet working alongside her for a full season, I learned that her envy over my potato and consequent joy over hers were not expressions of worries over stretching her income, building social networks or improving the quality of her diet. Her garden was a lifeline in crisis, but in another way. Zorka kept a plot because it offered her a sense of wellbeing and a chance at a normal life.

From the observations of the gardening style, attitudes and accounts of my neighbours on the plot and from my own experiences, I summed up five benefits of gardening for overcoming biographic impasses: it gives one a temporal structure, a sense of usefulness, a sense of social validation, a future prospect and a moral environment. All five benefits are the result of cultivating edible plants, yet not for economic purposes. Rather, they stem from their cultivation and harvest patterns and from their symbolic value.

The first benefit is building a temporal structure. Although the outcomes of urban horticulture cannot be predicted, its processes have fixed rhythms, repeating themselves in annual and daily cycles. A gardening season is the cumulative temporal coordination of organisms in the garden assemblage. In early spring you sow lettuce, radish, onions and carrots. You and all your garden neighbours plant tomato seedlings in mid-May and anticipate picking the first fruits in July. You fertilise your crops when others do. You water your garden in early morning or at sunset. You weed on a sunny day that follows a rainy one. You pickle your gherkins and enjoy them in winter while you plan a new gardening season. The steady rhythms open up a possibility of anticipation. Instead of jumping at every opportunity for fear of missing it, the investment of labour allows one to wait for the right moment when the outcome will be optimal. Working in the garden, one can see ahead, if only for the length of a gardening season. For a precarious life with little daily structure, these temporal anchors organise one's expectations and offer a sense of stability.

I observed the second self-making effect-feeling useful, indispensable - from the gardening style most often adopted on vegetable plots in Ljubljana. 'Classic' gardening, as well as more environmentally-friendly permaculture, treats the role of human labour as a resource to be optimised, either by increasing yields or by decreasing the amount of labour needed for that same expected yield-it employs the principles of mainstream economics. The gardener has several techniques at their disposal to inflate the yield, including carefully planning the season, 'intercropping', planting hybrid cultivars, using pesticides, and fortifying the garden beds with mulch to prevent the soil from drying out. However, I found none of these practices in the rota of techniques employed by my neighbours. Their gardening style seemed rather to invite extra work, without an apparent benefit to the yield. The plot-holders dedicated days of work to weeding and keeping the garden looking tidy. They picked pests by hand and inspected their plots regularly to spot them, they 
peeled the outer leaves of cruciferous plants to display an unblemished front to the neighbours - and pests. Even when a simpler one-time solution might have got the task done equally well, plot-holders refused to take the shortcut.

One could interpret the additional work as scepticism about adopting contemporary gardening techniques, but this would be inaccurate, as many newer methods such as preparing and using nettle-leaf plant food were regularly used. One could try suggesting, as several anthropologists did, that flaunting the assiduousness of labour might in itself be the purpose of work. A persisting thesis explains such behaviour as a remnant of the socialist labour theory of value, which rated production above consumption and self-sufficiency above commerce (Humphrey 1995). A more classic thought links the display of hard work with extracting social capital: gaining social esteem by showing off skill, like the subsistence horticulturalists on Trobriand Islands in Melanesia (Malinowski 1922, p. 60); or gaining integrity and moral character by signalling one's independence and willingness to climb out of poverty, like Hungarian peasants from the early twentieth century (Lampland 1995).

I found little resonance for these theories on the garden plots in Ljubljana. As I learned to grow vegetables, I began to understand what spending entire days on the plot engaged in seemingly superfluous tasks afforded. One gained a nearperfect overview of the processes in the garden: every looming pest danger, sprouting crop and weather shift. Keeping one's ear to the ground is paramount when one's survival rests on self-provisioning, as studies of subsistence farming elaborately show (Berger 1979). However, when subsistence concerns are absent (as they were on the urban plots in Ljubljana), efforts to replace a tool with labour-such as removing pests by hand instead of using a repellent—offer a different benefit. They make the gardener indispensable. Doing everything they can inscribes the grower into the garden and supplies a sense that the balance might topple without their enduring intervention and, thus, that their work matters. Doing everything one can also makes it easier to accept circumstances beyond one's control. When gardens were ransacked for fresh produce overnight, the gardeners quickly shrugged it off. "There is nothing you can do about it," an experienced gardener told me, "you just plant a bit more." The collapse of supporting social structures in a crisis makes lives harder to navigate. Plot gardening helps one regain a sense of control and feel that one's actions will have practical consequences, however uncertain. With this foundation, the ceaseless uncertainty of the plot can be tackled with acceptance.

The ease with which plot-holders handled vegetable-pilfering reflected the third benefit. It indicated that horticulture exercises a safety-in-numbers principle-it makes sense to grow more than you need. The same solution applies to many other eventualities—storms, drought, early snow, disease, bad seeds. Yet the uneven harvest distribution during peaks leaves growers with more vegetable crops than they can handle, even on small garden plots. Growing edible plants, therefore, necessitates a surplus. Gluts of some vegetables can be processed easily-cooked into sauces, pickled and frozen. The abundance of tomatoes or gherkins will always be met with joy. But certain crops-such as lettuce, cucumber or courgette-need to be eaten fresh. A surplus of these crops will induce worries that they will perish. In order to prevent the fruits of their labour from going to waste, plot-holders sought out social relationships with potential produce-recipients and donated gluts of perishable crops to more or less anyone who they suspected might enjoy them. Whether or not the plot-holders managed to make use of their surplus determined whether they themselves felt useful. Leaving the produce to perish felt as if they had thrown away their hard labour, rendering their work worthless. Finding useful ends for their gluts, whether in the pantry or as gifts to a grateful recipient, realised their labour investment. Converting their labour into valuable nourishment gave it meaning. Only this last step of gardening transformed the exertion of their energy into a social good. Gardeners were usually vehemently opposed to selling their gluts (unless this was their goal from the start). A price put on their work would devalue it, exchanging surplus for cash would miss the opportunity to fashion themselves as social beings.

Ethnographers have proposed that the purpose of growing food in postsocialist Central European cities was to produce an informal currency capable of sustaining networks of mutual aid in the absence of state welfare (see Czegledy 2002). Ljubljanian gardeners revealed quite the reverse to be true: their wish to utilise their produce precipitated sociable behaviour. Gardening was aimed not toward building social networks, but toward socially recognised labour and the sense of agency it afforded. The produce itself was merely a promise toward which the gardeners hedged their investment of labour. By including the recipients of their vegetable gluts, the growers insured themselves against loss. At the same time, they received validation of their worth as producers of social goods and alleviated the feeling of uselessness that comes with unemployability.

I noticed the contours of the fourth effect-finding meaning by cultivating a sense of a prospect-after the responses to my question about why plot-holders kept their plots began to reveal a pattern. Recall the reply I received from the longterm growers about their motives for the activity. "You save a bit of money, you grow some fresh vegetables, get some fresh air and a bit of exercise... and you make some good company", my collocutors told me. There was a catch: their responses were almost identical. Plot-holders with very different backgrounds listed an intriguingly uniform array of gardening benefits as their personal rationale. These came irrespective of whether they were indeed passionate about 
exercising, in financial need, nourishing particular culinary pleasures or fond of socialising. After I started tending my plot, I found that this blanket statement fit my own experience, but not as an articulation of the motivation for gardening prior to the activity. Instead, I recognised these explicit benefits as descriptions of the outcomes-the side-effects of gardening - and as constructed retrospectively to justify the investment of labour. Since so much time and energy was sacrificed for it, the activity had to have some positive effect. Gardeners, although reluctant to spend their labour for nothing, did not seem finicky about which particular aim was a worthy one.

The strongest appeal of the practice of gardening lay not with what you got out of it, but with what you put in. By investing their efforts into the garden, the plot-holders became invested in using their effort in (any) meaningful way, because the alternative-that they were wasting their time-would simply be crushing. The investment of work toward an abundant harvest allowed the gardener to take the harvest outcome, over which they had little actual control, as reflecting something about themselves. Gardeners interpreted a good harvest as reward for their work. Crop-failure was perceived as misfortune or injustice. Interpreting harvests as evaluations of the gardener's moral character added drama and plot-movement to their biographical narrative. The dynamic, yet chance outcomes of the gardening seasons were translated into the ups and downs of life. By transforming uncertainty into a meaningful plot in this way, life was no longer freewheeling, but headed in a certain direction.

Fifth and finally, by working on the plot, Ljubljanians could model their biographical narratives into a particular genre. The garden assemblage functioned as an alternative moral landscape on which their self-narratives could play out. Especially since the economic slump of the kriza, Ljubljanians have felt increasingly excluded from principles of achieving prosperity. While they observed wealth being channelled into the hands of managerial swindlers and financial speculators by the conjurings of the 'occult economies' (see Comaroff and Comaroff 1999) and with support of the nation state and the EU, they saw little improvement in their own affluence (Dragoš 2016). In the vegetable garden, they could critique this state of affairs and assert an alternative morality (Ries 2009), one that reinstated hard and dedicated work as a path to social mobility and success. Here, they could make their work count. When work and the accumulation of work into experience are the only things one can use to influence the results of the gardening season in one's favour, diligence and seniority are recognised as the most important personal characteristics. By cultivating vegetables, the gardeners participated in a concept of social equality envisioned as a level playground, where effort and merit propel one the furthest. Everyone starts from the same position on the plot and has an equal chance at success. One cannot reach for abundance by merely grabbing a larger piece of the pie, acquiring a larger plot of land. Tending a bigger plot requires more work and more experience.

Growing vegetables was particularly suitable for such a moral project because vegetables can express a commitment to work better than other plants. Growing decorative plants and fruit was regarded by the plot-holders as leisurely, workshy and undemanding, and was discouraged by the DGA organisation. The way the gardeners reported on the progress of their vegetable plants further suggested that the plants had been chosen for their ability to reflect work. Instead of the more formal verb uspevati (to flourish), plot-holders referred to the plant with the verb delati (to work), as in "finally, the peas have begun to work" or "last season the tomatoes were working until late autumn" (see Degnen 2009 for further discussion of ascribing intentionality to plants). Furthermore, root vegetables are particularly fruitful for evaluating one's moral worth because the results, submerged in the soil, need to be patiently awaited before they are revealed. An ethnographic account of flower cultivation in Mozambique shows young single men, who felt reluctant to participate in uncommitted, short-term romantic relationships, but were longing for love, growing decorative plants as their chosen pastime (Archambault 2016). Flowers were so suitable as the recipients of the Mozambican men's expressions of pure, authentic love because they had no utility-no medical properties, no underground parts that could be used in sorcery. With everything out in the open, visible to the naked eye, the plant had to be taken for what it was, not what it was for. This conception of truth, as that which lies on the surface, is the exact opposite of truth envisioned in Ljubljana-as something to be uncovered, worked towards, as that which eludes appearance. The morals of the working class in CEE and FSU abhor pretence and performance and distrust the immediately apparent. For postsocialist citizens, the true markers of value are the under-the-counter, in-the-back, offlabel items accessible to those with insider knowledge and connections (Humphrey 1995). Root vegetables functioned similarly. Once I had dug out our abundant beds of potatoes, the potatoes lay at my feet as a reward for my labour and as evidence of my character and hard work. This irked Zorka. In her view, I wasn't experienced enough to deserve such plenitude - and she was. Her later declaration of a uniquely fruitful season after the unveiling of her own exceptional potato-crop restored equality on the plot, put me in my place, and resolved the drama.

\section{Concluding discussion}

Rather than arguing that urban horticulture equips growers with practical skills and goods that increase their personal autonomy in times of disruption, in this article I have 
proposed that urban agriculture in Ljubljana gives growers several tools for thinking about themselves as agents: a temporal structure, a moral environment and a social role with significance to themselves and to others. Sentiments that arose on the Ljubljanian gardens during the European debt crisis indicated a need to author one's own life-story, not just to live one written by circumstances. In the absence of social sources of security and predictability, Ljubljanian plot-holders found the bones for structure in the garden assemblage. They fleshed out the near future by attuning themselves with the garden calendar; becoming indispensable to their environment; producing social value with tangible results; creating a sense of biographical development; and spending time among moral equals. Urban gardening alleviates precarity because it gives the gardener a greater sense of control over their life, without reducing the opportunity for chance occurrence and surprise. These findings cast a different light onto the benefits of urban gardening for health and wellbeing. They point toward the central role of meaningful, socially significant work and its power to structure lives. Urban plot gardening was first and foremost a narrative activity by which Ljubljanians made sense of their lives lived in precarity. The spike of interest in gardening around the world during the Covid-19 pandemic lockdowns (Mendelson 2020; Smithers 2020) attests to our need to give shape to the passing of time and to the ability of gardening to provide this structure.

I have shown that explaining the motivation that fuelled the increase in urban gardening during the European debt crisis in Ljubljana required a shift from conceptions of inequality based primarily on subsistence and access to economic goods to a conception that included the politics of precarity. The increase in the number of gardening practitioners during the recession years reflected a desire to mend biographies broken by the economic crisis. This predicament is perhaps best captured by Monty Don, the British gardening TV presenter, describing vegetable growing as: "When you plant something, you invest in a beautiful future amid a stressful, chaotic and, at times, downright appalling world" (Saner 2019, paragraph 5). However, researchers of urban agriculture should be wary of focusing disproportionately on the 'beautiful future' that gardening represents, rather than on the 'appalling world' that it helps mitigate. The most potent implications of the findings in this paper will adopt the lens of scholars who researched self-provisioning in CEE after the collapse of socialism. They asked, what do city gardens grant that societies no longer do?

In marginalised urban areas in the United States, such as Detroit or West Oakland, urban agriculture has been a vehicle of addressing specific urban ills, such as food deserts, food injustice or lack of access to community space, in a targeted way (see McClintock 2008; Draus et al. 2014). This explicit political voice is inaccessible to most urban growers in Ljubljana, who practise urban agriculture privately, in a non-organised and non-collective way, under land-use rights that are often unclear. With the recognition that a political charge is not an inherent characteristic of urban gardening, this paper has explored urban agriculture in Ljubljana as an opportunity for implicit social and political critique. The paper adds further proof for the need to analyse time-use, time-allocation and exposure to uncertainty and to risks as factors of social class and social justice. It attests to the importance of understanding precarity as a multiple force that animates emotions, social reproduction strategies, relationships of care, as well as social polarity and hierarchies, which, in turn, shape urban environments (see Doshi 2017). It calls for social and urban policy that does not focus merely on helping urban gardens to thrive; that does not regard household food-production as a panacea for urban ills; but that, rather, harnesses the notion of urban agriculture as a viable response to living in uncertain times and that is willing to challenge the established strategies of targeting inequality and poverty.

Acknowledgements The paper benefited from the comments of five anonymous reviewers and reading by Elizabeth Teague, Helen Underhill, Anna Colquhoun and Camelia Dewan. Thank you to all, for helping me make myself clear.

\section{References}

Adorno, T.W. 2001. The stars down to earth and other essays on the irrational in culture. London and New York: Routledge.

Alber, J., and K. Ulrich. 2008. Informal food production in the enlarged European Union. Social Indicators Research 89 (1): 113-127.

Altieri, M.A., N. Companioni, K. Cañizares, C. Murphy, P. Rosset, M. Bourque, and C.I. Nicholls. 1999. The greening of the 'barrios': Urban agriculture for food security in Cuba. Agriculture and Human Values 16 (2): 131-140.

Anderson, L. 2006. Analytic autoethnography. Journal of Contemporary Ethnography 35 (4): 373-395.

Archambault, J.S. 2016. Taking love seriously in human-plant relations in Mozambique: Toward an anthropology of affective encounters. Cultural Anthropology 31 (2): 244-271.

Berger, J. 1979. Introduction. In Pig earth, xi-xxvii, ed. J. Berger. New York: Pantheon Books.

Berlant, L.G. 2011. Cruel optimism. Durham: Duke University Press.

Berman, M.G., J. Jonides, and S. Kaplan. 2008. The cognitive benefits of interacting with nature. Psychological Science 19 (12): 1207-1212.

Bhatti, M., and A. Church. 2001. Cultivating natures: Homes and gardens in late modernity. Sociology 35 (2): 365-383.

Bourdieu, P. 2000. Social being, time and the sense of existence. In Pascalian meditations, ed. P. Bourdieu, 206-245. Stanford: Stanford University Press.

Bridger, S., and F. Pine, eds. 1998. Surviving post-socialism: Local strategies and regional responses in Eastern Europe and the former Soviet Union. London and New York: Routledge.

Bruner, J. 2003. Self-making narratives. In Autobiographical memory and the construction of a narrative self: Developmental and Cultural Perspectives, ed. R. Fivush and C.A. Haden, 209-226. Mahwah, New Jersey: Lawrence Erlbaum Associates. 
Bryant, R. 2016. On critical times: Return, repetition, and the uncanny present. History and Anthropology 27 (1): 19-31.

Bryant, R., and D. Knight. 2019. The anthropology of the future. Cambridge: Cambridge University Press.

Burnik, I., S. Dokl, M. Kos, F. Milošič, P. Potčonik, M. Repovž, L. Stružnik, V. Širec, M. Šoštarič, and M. Kaučič. 1984. Organizirano vrtičkarstvo je priložnost za znižanje stroškov družinskega proračuna in prispevek k samooskrbi. Delo, June 8.

Butler, J. 2004. Precarious life: The power of mourning and violence. London, New York: Verso Books.

Caldwell, M.L. 2011. Dacha idylls: Living organically in Russia's countryside. Berkeley: University of California Press.

Clarke, S., L. Varshavskaya, S. Alasheev, and M. Karelina. 2000. The myth of the urban peasant. Work, Employment \& Society 14 (3): 481-499.

Comaroff, J., and J.L. Comaroff. 1999. Occult economies and the violence of abstraction: Notes from the South African postcolony. American Ethnologist 26 (2): 279-303.

Czegledy, A. 2002. Urban peasants in a post-socialist world: Smallscale agriculturalists in Hungary. In Post-socialist peasant? Rural and urban constructions of identity in Eastern Europe, East Asia and the former Soviet Union, ed. P. Leonard and D. Kaneff, 200-220. Houndmills, Basingstoke, Hampshire; New York: Palgrave.

De Boeck, F. 2015. 'Poverty' and the politics of syncopation: Urban examples from Kinshasa (DR Congo). Current Anthropology 56 (S11): S146-S158.

Degnen, C. 2009. On vegetable love: Gardening, plants, and people in the north of England. Journal of the Royal Anthropological Institute 15 (1): 151-167.

DeLind, L. 1999. Close encounters with a CSA: The reflections of a bruised and somewhat wiser anthropologist. Agriculture and Human Values 16 (1): 3-9.

Desjarlais, R. 1997. Shelter blues: Sanity and selfhood among the homeless. Philadelphia: University of Pennsylvania Press.

Doshi, S. 2017. Embodied urban political ecology: Five propositions. Area 49 (1): 125-128.

Dragoš, S. 2016. Socialna država in solidarnost. Teorija in Praksa 53: $148-173$.

Draus, P.J., J. Roddy, and A. McDuffie. 2014. 'We don't have no neighbourhood': Advanced marginality and urban agriculture in Detroit. Urban Studies 51 (12): 2523-2538.

Dunn, E.C. 2008. Postsocialist spores: Disease, bodies, and the state in the Republic of Georgia. American Ethnologist 35 (2): 243-258.

Dwiartama, A., and C. Piatti. 2015. Assembling local, assembling food security. Agriculture and Human Values 33 (1): 153-164.

Ferreira, A.J., R.I. Guilherme, C.S.S. Ferreira, and M. de Fátima Martins Lorena de Oliveira. 2018. Urban agriculture, a tool towards more resilient urban communities? Current Opinion in Environmental Science \& Health 5: 93-97.

Filipovič Hrast, M., and T. Rakar. 2015. The future of the Slovenian welfare state and challenges to solidarity. Proceedings of the 13th Annual ESPAnet conference - The lost and the new worlds of welfare, 3-15 September 2015, Odense, Denmark: 1-25.

Gan, E., and A. Tsing. 2018. How things hold. Social Analysis 62 (4): 102-145.

Ginn, F. 2012. Dig for Victory! New histories of wartime gardening in Britain. Journal of Historical Geography 38 (3): 294-305.

Guardiancich, I. 2013. The downfall of Slovenia, and why it matters for Europe. The Conversation. http://theconversation.com/the-downf all-of-slovenia-and-why-it-matters-for-europe-19180. Accessed 12 June 2021.

Gudeman, S., and C. Hann. 2015. Introduction. Self-sufficiency as reality and as myth. In Oikos and market: Explorations in selfsufficiency after socialism, ed. S. Gudeman and C. Hann, 1-23. New York: Berghahn Books.
Gudeman, S., and A. Rivera. 1990. Conversations in Colombia: The domestic economy in life and text. Cambridge: Cambridge University Press.

Gupta, A., and J. Ferguson. 1997. Anthropological locations: Boundaries and grounds of a field science. Berkeley: University of California Press.

Hage, G. 2009. Waiting out the crisis: On stuckedness and governmentality. In Waiting, ed. G. Hage, 97-106. Carlton, Victoria: Melbourne University Publishing.

Haraway, D. 2008. When species meet. Minneapolis: University of Minnesota Press.

Hervouet, R. 2003. Dachas and vegetable gardens in Belarus: Economic and subjective stakes of an 'ordinary passion.' Anthropology of East Europe Review 21 (1): 159-168.

Humphrey, C. 1995. Creating a culture of disillusionment: Consumption in Moscow, a chronicle of changing times. In Worlds apart: Modernity through the prism of the local, ed. Daniel Miller, 43-68. London and New York: Routledge.

Intihar, Stanka. 2017. Kazalniki dohodka, revščine in socialne izključenosti, Slovenija, 2016. Ljubljana: Statistični urad republike Slovenije.

Jamnik, B., A. Smrekar, and B. Vrščaj. 2009. Vrtičkarstvo v Ljubljani. Ljubljana: Založba ZRC.

Jansen, S. 2015. Yearnings in the meantime: "normal lives" and the state in a Sarajevo apartment complex. New York: Berghahn.

Jehlička, P., and J. Smith. 2011. An unsustainable state: Contrasting food practices and state policies in the Czech Republic. Geoforum 42 (3): 362-372.

Jung, Y. 2014. Ambivalent consumers and the limits of certification: Organic foods in postsocialist Bulgaria. In Ethical eating in the postsocialist and socialist world, ed. Y. Jung, J. Klein, and M.L. Caldwell, 93-115. Berkeley, Los Angeles and London: University of California Press.

Khosravi, S. 2017. Precarious lives: Waiting and hope in Iran. Philadelphia: University of Pennsylvania Press.

Lampland, M. 1995. The object of labor: Commodification in socialist Hungary. Chicago: University of Chicago Press.

Lyson, T.A. 2012. Civic agriculture: Reconnecting farm, food, and community. Hannover and London: University Press of New England.

Malinowski, B. 1922. Argonauts of the western Pacific: An account of native enterprise and adventure in the archipelagoes of Melanesian New Guinea. New York: Dutton.

Marcus, G.E. 1995. Ethnography in/of the world system: The emergence of multi-sited ethnography. Annual Review of Anthropology 24: 95-117.

McClintock, N. 2008. From industrial garden to food desert: Unearthing the root structure of urban agriculture in Oakland, California. UC Berkeley: Institute for the Study of Societal Issues. https:// escholarship.org/uc/item/1wh3v1sj. Accessed 12 June 2021.

McClintock, N., C. Miewald, and E. McCann. 2018. The politics of urban agriculture. In The Routledge handbook on spaces of urban politics, ed. K. Ward, A. Jonas, B. Miller, and D. Wilson, 361374. Taylor \& Francis Group: Routledge.

Mendelson, C. 2020. The tonic of gardening in quarantine. The New Yorker. April 7. https://www.newyorker.com/culture/onwardand-upward-in-the-garden/the-tonic-of-gardening-in-quarantine. Accessed 12 June 2021.

Millar, K. 2014. The precarious present: Wageless labor and disrupted life in Rio de Janeiro Brazil. Cultural Anthropology 29 (1): 32-53.

Mintz, S.W. 1979. The anthropological interview and the life history. The Oral History Review 7 (1): 18-26.

Mroczkowska, J. 2019. Pork politics: The scales of home-made food in Eastern Poland. Appetite 140: 223-230.

Muehlebach, A. 2012. The moral neoliberal: Welfare and citizenship in Italy. Chicago: University of Chicago Press. 
Müller, M. 2015. Assemblages and actor-networks: Rethinking sociomaterial power, politics and space. Geography Compass 9 (1): $27-41$.

Narotzky, S., and N. Besnier. 2014. Crisis, value, and hope: Rethinking the economy: An introduction to supplement 9. Current Anthropology 55 (S9): S4-S16.

Nogeire-McRae, T., E.P. Ryan, B.B.R. Jablonski, M. Carolan, H.S. Arathi, C.S. Brown, H.H. Saki, S. McKeen, E. Lapansky, and M.E. Schipanski. 2018. The role of urban agriculture in a secure, healthy, and sustainable food system. BioScience 68 (10): 748-759.

O’Neill, B. 2014. Cast aside: Boredom, downward mobility, and homelessness in post-Communist Bucharest. Cultural Anthropology 29 (1): 8-31.

Ochs, E., and L. Capps. 1996. Narrating the self. Annual Review of Anthropology 25: 19-43.

Ochs, E., and L. Capps. 2001. Living narrative: Creating lives in everyday storytelling. Cambridge, Massachusetts: Harvard University Press.

OECD. 2001. OECD Review of agricultural policies: Slovenia 2001. Paris: OECD Publishing.

Pine, F. 2002. Retreat to the household? Gendered domains in postsocialist Poland. In Postsocialism: Ideals, ideologies and practices in Eurasia, ed. C. Hann, 95-113. London and New York: Routledge.

Poulsen, M.N. 2017. Cultivating citizenship, equity, and social inclusion? Putting civic agriculture into practice through urban farming. Agriculture and Human Values 34 (1): 135-148.

Pudup, M.B. 2008. It takes a garden: Cultivating citizen-subjects in organized garden projects. Geoforum 39 (3): 1228-1240.

Ries, N. 2009. Potato ontology: Surviving postsocialism in Russia. Cultural Anthropology 24 (2): 181-212.

Round, J., C. Williams, and P. Rodgers. 2010. The role of domestic food production in everyday life in post-Soviet Ukraine. Annals of the Association of American Geographers 100 (5): 1197-1211.

Sacks, O. 2019. Everything in its place: First loves and last tales. London: Pan Macmillan.

Saner, E. 2019. Ecotherapy: why plants are the latest treatment for depression and anxiety. The Guardian, August 26. https://www. theguardian.com/lifeandstyle/shortcuts/2019/aug/26/ecotherapyplants-treatment-depression-anxiety. Accessed 12 June 2021.

Schatzki, T.R. 2010. The timespace of human activity: On performance, society, and history as indeterminate teleological events. Plymouth: Lexington Books.

Smith, J., and P. Jehlička. 2013. Quiet sustainability: Fertile lessons from Europe's productive gardeners. Journal of Rural Studies 32: $148-157$.

Smithers, R. 2020. Interest in allotments soars in England during coronavirus pandemic. The Guardian, August 8. https://www.thegu ardian.com/lifeandstyle/2020/aug/10/interest-in-allotments-soarsin-england-during-coronavirus-pandemic. Accessed 12 June 2021.

Stenning, A., A. Smith, A. Rochovská, and D. Świątek, eds. 2011. Domesticating neo-liberalism: Spaces of economic practice and social reproduction in post-socialist cities. New Jersey: John Wiley \& Sons.

SURS. 2012. Anketa o porabi v gospodinjstvih (APG) 2012. Statistični urad republike Slovenije [Statistical Office of Republic of Slovenia].

SURS. 2014. Statopis - Statistični pregled Slovenije 2014. Ljubljana: Statistični urad republike Slovenije [Statistical Office of Republic of Slovenia].

Thorpe, H. 1975. The homely allotment: From rural dole to urban amenity a neglected aspect of urban land use. Geography 60 (3): $169-183$.

Tilley, C. 2008. From the English cottage garden to the Swedish allotment: Banal nationalism and the concept of the garden. Home Cultures 5 (2): 219-249.

Vrtičkarstvo v Ljubljani. 2016. Zelena prestolnica Evrope 2016. http:// www.zelenaljubljana.si/zelena-dejstva/vrtickarstvo-v-ljubljani. Accessed 4 May 2017.

Wachsmuth, D., and H. Angelo. 2018. Green and gray: New ideologies of nature in urban sustainability policy. Annals of the American Association of Geographers 108 (4): 1038-1056.

Wacquant, L. 1998. The prizefighter's three bodies. Ethnos 63 (3-4): 325-352.

Williams, R. 1977. Marxism and literature. Oxford: Oxford Paperbacks.

Zavisca, J. 2003. Contesting capitalism at the post-Soviet dacha: The meaning of food cultivation for urban Russians. Slavic Review 62 (4): 786-810.

Zorc, M. 2013. Gospodarska kriza v Sloveniji in ukrepi za izhod iz nje. In $Z$ znanjem do idej za nov zagon gospodarstva Zbornik 10. festivala raziskovanja ekonomije in managementa, ed. M. Zorc, 125-134. Fakulteta za management Koper: Koper.

Publisher's Note Springer Nature remains neutral with regard to jurisdictional claims in published maps and institutional affiliations.

Petra Matijevic is an independent researcher and consultant. She earned a Ph.D in Social Anthropology from SOAS, University of London and was postdoctoral Research Associate at UCL School of Slavonic and East European Studies. 